\title{
EFFECT OF SPRAYING POTASSIUM IODIDE ON PRODUCTIVE PERFORMANCE, BLOOD PARAMETERS AND IMMUNO-RESPONSE OF TURKEY CHICKS
}

\author{
El-Sawy, M.A. and Samya E. Ibraheim \\ Animal Production Research Institute, Agricultural Research Center, Ministry of \\ Agriculture, Giza, Egypt. \\ E.mail: elsawy1966@Gmail.com
}

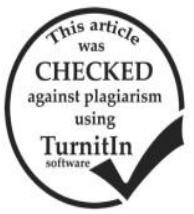

\begin{abstract}
A total of 120 one day-old Nicholas turkey chicks were divided randomly into six equal groups. The first and second groups were treated with distilled water (once and twice weekly) and served as control (T1 and T2), the third and forth groups (T3 and T4) were treated with 5\% potassium iodide (KI) solution once and twice weekly, respectively, while fifth and sixth (T5 and T6) groups were treated with $10 \%$ potassium iodide (KI) solution once and twice weekly, respectively. The treatments were spraying over chick heads. The chicks were kept at rearing wire cages, and the feed and water were available ad libitum. At 45 days of age ten birds from each group were intramuscularly injected with $0.5 \mathrm{ml}$ of SRBCs. The obtained results showed that chicks sprayed with $10 \% \mathrm{KI}$ showed the highest LBW and gain $(\mathrm{P}<0.05)$ at 30,45 and 60 days of age, followed by $5 \% \mathrm{KI}$, while the control showed the lightest weights and gain. LBW and gain of chicks at 60 days of age was higher $(\mathrm{P}<0.05)$ for spraying once than twice/week. Both KI levels increased $(\mathrm{P}<0.05)$ WBCs count and blood hemoglobin $(\mathrm{Hb})$ concentration as compared to control. Chicks in $10 \% \mathrm{KI}$ treatment showed the highest $(\mathrm{P}<0.05)$ WBCs count and $\mathrm{Hb}$ concentration. WBCs count was higher $(\mathrm{P}<0.05)$ by spraying the chicks twice/week than once/week. RBCs count and $\mathrm{Hb}$ concentration were nearly similar as affected by spraying time. Serum total protein (TP) concentration increased $(\mathrm{P}<0.05)$ with $10 \% \mathrm{KI}$ as compared to control, but did not differ from that with $5 \%$ KI. Globulin (GL) concentration increased $(\mathrm{P}<0.05)$ and albumin $(\mathrm{AL})$ was not affected by $10 \% \mathrm{KI}$. However, $\mathrm{AL} / \mathrm{GL}$ ratio increased $(\mathrm{P}<0.05)$ with $5 \% \mathrm{KI}$ as compared to control, but did not differ from that with $10 \% \mathrm{KI}$. There were insignificant differences in AST and ALT activities. Serum T3 concentration was the highest $(\mathrm{P}<0.05)$ with $10 \% \mathrm{KI}$, followed by $5 \% \mathrm{KI}$ and the lowest in control, respectively. T3 concentration was higher $(\mathrm{P}<0.05)$ by spraying twice than once/week. Chicks treated with $10 \%$ KI showed the highest $(\mathrm{P}<0.05)$ antibody titer and the lowest $(\mathrm{P}<0.05)$ lysozyme concentration, followed by $5 \% \mathrm{KI}$, while the control showed the lowest antibody titer and the highest lysozyme concentration $(\mathrm{P}<0.05)$. Spraying twice/week increased $(\mathrm{P}<0.05)$ antibody titer and decreased lysozyme concentration, reflecting the highest immune response for chicks treated with $10 \% \mathrm{KI}$ twice/week.

It could be concluded that potassium iodide had positive effect on turkey chicks when used as spraying over heads of growing chicks with $10 \%$ once a week.
\end{abstract}

Keywords: Turkey chicks, iodine, growth performance, blood, immunity.

\section{INTRODUCTION}

The importance of iodine as an essential element in animal's diet arises from the fact that it is a major component of the thyroid hormone, tri-iodothyronine $\left(\mathrm{T}_{3}\right)$ and, tetra-iodothyronine $\left(\mathrm{T}_{4}\right)$ or thyroxine (Ganong, 2001). It has an important effect on thyroid gland (AbdEl-Latif et al., 2001). The thyroid gland contains the highest concentration of iodine $(0.2-5 \%$ on a dry weight basis) in the body; to be $70-80 \%$ of the total body iodine stores. Approximately $90 \%$ of the iodine which passes through the thyroid gland is captured by that organ (Hetzel and Welby, 1997). Iodine is combined with tyrosine in the thyroid to form diiodotyrosine, then two molecules of diiodotyrosine are combined to form thyroxine molecule. Approximately $80 \%$ of thyroxine in blood circulation is broken down through de-iodination in liver, kidney and other tissues (Gado, 1996).

Thyroid hormones regulate metabolic activity and promote growth. The importance of iodine is considered as limited element for thyroidal hormones $\left(\mathrm{T}_{3}\right.$ and $\left.\mathrm{T}_{4}\right)$ biosynthesis (Magilvery, 1979). Deficiency of dietary iodine can be solve by re-utilization of released iodine from degradation of thyroid hormones (Sturkie, 1986). The mode of action of thyroid hormones could be divided into two general ways, the first is metabolic effects as calorigenesis, regulation transportation of water and ions and regulation of intermediary metabolism; and the second is their growth-promoting developmental action (Hadlley, 1992; McNabb and King, 1993). Thyroid gland cannot synthesize its hormones without adequate amount of iodine in blood. At the same time, inadequate amount of iodine not only reduces activity of thyroid hormone, but also cause hypertrophy of thyroid gland. Thyroid gland consumes about 70-100 $\mu \mathrm{g}$ of iodine daily for hormone synthesis (Turner and Bagna, 1971).

Hamdy and Abd El-Latif,(1999) revealed that supplementing drinking water with potassium iodide (KI) at levels of 300 and $600 \mathrm{ppm}$ improved age of sexual maturity, egg number, egg weight and feed conversion ratio in Japanese quail hens. While adding a level of $900 \mathrm{ppm}$ of KI showed an opposite results in egg number, egg weight, and feed conversion ratio. Other investigators found that $\mathrm{KI}$ had antimicrobial effects against wide range of microbes, gram (negative and positive) bacteria species (Cooper, 2007), due to developing of general healthy including immunity and growth performance.

The present study was conducted to investigate the effect of spraying KI on productive performance, blood parameters and immune-response of growing turkey chicks during the first 60 days of age.

\section{MATERIALS AND METHODS}

This study was carried out at the Turkey Breeding Station, Mahallet Mousa, Kaferelsheikh Governorate, Animal Production Research Institute, Agricultural Research Center, Egypt.

Birds and feeding system:

A total number of 120 one day-old Nicholas turkey chicks were used in this study. Birds were 


\section{El-Sawy, M.A. and Samya E. Ibraheim}

divided randomly into six similar groups in wire cages. Water and feed were available ad. libitum all times. Birds in all groups were fed commercial diet containing $0.4 \mathrm{mg}$ iodine $/ \mathrm{kg}$ during 60 days as an experimental period Ingredients and calculated energy and $\mathrm{CP}$ contents are shown in Table (1).

Iodine content of feed was determined according to McDowell (2003).

Table (1): Ingredients and calculated energy and CP contents of the basal diet.

\begin{tabular}{|c|c|}
\hline Ingredient & Diet from 0-60 days \\
\hline Yellow corn & 60.0 \\
\hline Wheat bran & 0.60 \\
\hline Soybean meal (44\%) & 39.0 \\
\hline Broiler concentrate $(50 \%)$ & 10.0 \\
\hline Limestone & 0.00 \\
\hline Bone meal & 0.30 \\
\hline Iodine $(\mathrm{mg} / \mathrm{kg})$ & 0.4 \\
\hline Premix* & 0.10 \\
\hline Total & 100 \\
\hline \multicolumn{2}{|l|}{ Calculated chemical composition $* *$ : } \\
\hline Metabolizable energy ME (Kcal /kg) & 2900 \\
\hline Crude protein $(\%)$ & 26.90 \\
\hline
\end{tabular}

\section{Experimental design:}

Six treatments were used in this study. Birds in the control groups (T1 and T2) were subjected to spraying with distilled water once or twice, respectively, while those of treatments T3 to T6 were subjected to spraying over heads with $10 \mathrm{ml}$ (volume of solution) contained 5 or $10 \%$ KI once and twice weekly, respectively (Table 2 ).

Table (2): Experimental design of treatments.

\begin{tabular}{lcc}
\hline Treatment & No. of birds & Spraying time (KI level/week) \\
\hline T1 & 20 & Distilled water once a week \\
T2 & 20 & Distilled water twice a week \\
T3 & 20 & $5 \%$ KI* once a week \\
T4 & 20 & $5 \%$ KI twice a week \\
T5 & 20 & $10 \%$ KI once a week \\
T6 & 20 & $10 \%$ KI twice a week \\
\hline
\end{tabular}

* KI: Potassium Iodide (a commercial product $2.5 \%$ I, diluted with distilled water to obtain 5 or $10 \%$ I solutions).

\section{Experimental procedures:}

During an experimental period of 60 days, birds were weighed to record live body weight (LBW) at one day old and biweekly thereafter. Body weight gain (BWG) was calculated at biweekly intervals and during the whole experimental period.

On day 45 of age, 10 chicks from each group were injected intramuscularly with $0.5 \mathrm{ml}$ of $50 \%$ sheep red blood cells (SRBC) as T-dependent antigen. Blood samples were collected at the end of the experimental period (60 days of age) and divided into two aliquots. In the first one, count of red blood cells (RBCs) and white blood cells (WBCs) was determined using haemocytometer (Hawkey and Dennett, 1989). Haemoglobin $(\mathrm{Hb})$ concentration was measured according to Drew et al. (2004). The second aliquot of blood sample was centrifuged at $3500 \mathrm{rpm}$ for 15 minutes to obtain serum and immediately stored at $-20^{\circ}$ until analysis. Concentration of serum total protein and albumin as well as activity of asprtate (AST) and alanine (ALT) transaminases were determined coloremetrically using available commercial kits (BioMerius, France). Cncentration of serum $\mathrm{T}_{3}$ was determined by radioimmunoassay (RIA) as described by Darras et al. (1992).
Humeral Immune Response was evaluated by haemaglutination (HA) test according to Prescott et al. (1982). Titers were measured as $\log 2$ values. Haemaglutination anti-bodies were assessed 7 days later by HA test. Measurement of lysozyme activity was determined according to the method described by Schltz (1987).

\section{Statistical analysis:}

Data were subjected to statistical analysis using SAS (1995) according to the following model: $Y_{i j k}=\mu+T_{i}$ $+F_{j}+T F_{i j}+e_{i j k}$ Where: $\mathrm{Y}_{\mathrm{ijk}}=$ the observation of individuals, $\mu=$ overall mean, $\mathrm{T}_{\mathrm{i}}=$ effect of treatment (Iodine level, 0, 5 and 10\%), $\mathrm{F}_{\mathrm{j}=\text { effect }}$ of spraying time (once or twice weekly), $\mathrm{TF}_{\mathrm{ij}}=$ effect of interaction between treatments and time, and $\mathrm{e}_{\mathrm{ijk}}=$ experimental error or residual. Means were separated using Duncan's Multiple Range Test (Duncan, 1955).

\section{RESULTS}

\section{Productive performance:}

Live body weight:

Data presented in Table (3) showed that the significant $(\mathrm{P}<0.05)$ effect of $\mathrm{KI}$ treatment appeared on LBW of chicks at 30, 45 and 60 days of age. Chicks sprayed at a level $10 \% \mathrm{KI}$ were significantly $(\mathrm{P}<0.05)$ 
the heaviest at 30, 45 and 60 days of age, followed by those sprayed with $5 \%$, while control chicks showed the lightest weights.

The effect of spraying time on LBW of chicks was not significant at $0,15,30$ and 45 days of age. However, LBW of chicks at 60 days of age was significantly $(\mathrm{P}<0.05)$ higher for spraying once than twice/week. The effect of interaction between treatment and spraying time was significant $(\mathrm{P}<0.05)$ at 30,45 and 60 days of age, reflecting the heaviest LBW of chicks sprayed with KI at a level of $10 \%$ for once/week at these ages. However, the least LBW was obtained for those sprayed with water for once/week (Table 3).

Table (3): Live body weight of turkey chicks at different ages as affected by treatment, spraying time and their interaction.

\begin{tabular}{|c|c|c|c|c|c|}
\hline \multirow{2}{*}{ Variable } & \multicolumn{5}{|c|}{ Live body weight (g) at different ages } \\
\hline & Day one & Day 15 & Day 30 & Day 45 & Day 60 \\
\hline \multicolumn{6}{|c|}{ Effect of treatment (KI level): } \\
\hline $0 \%$ & 60.63 & 218.9 & $1936.8^{\mathrm{c}}$ & $2830.9^{c}$ & $3634.8^{\mathrm{c}}$ \\
\hline $5 \%$ & 60.58 & 214.7 & $1978.1^{\mathrm{b}}$ & $2973.6^{\mathrm{b}}$ & $3879.2^{b}$ \\
\hline $10 \%$ & 60.59 & 220.7 & $2064.6^{\mathrm{a}}$ & $3156.4^{\mathrm{a}}$ & $4298.0^{\mathrm{a}}$ \\
\hline$\pm \mathrm{SEM}$ & 0.13 & 0.33 & 5.20 & 39.2 & 40.80 \\
\hline \multicolumn{6}{|c|}{ Effect of spraying time/week: } \\
\hline Once $(\mathrm{O})$ & 60.23 & 219.2 & 1997.6 & 2967.6 & $4235.0^{\mathrm{a}}$ \\
\hline Twice (T) & 60.96 & 216.7 & 1992.4 & 2974.0 & $3939.6^{b}$ \\
\hline$\pm \mathrm{SEM}$ & 0.11 & 0.29 & 3.9 & 32.2 & 39.1 \\
\hline \multicolumn{6}{|c|}{ Interaction between treatment and spraying time: : } \\
\hline $\mathrm{O} \times 0 \%$ & 60.13 & 218.5 & 1935.7 & 2821.4 & 3623 \\
\hline $\mathrm{O} \times 5 \%$ & 59.30 & 214.0 & 1942.7 & 2964.8 & 3791.4 \\
\hline $\mathrm{O} \times 10 \%$ & 61.27 & 225.2 & 2114.3 & 3213.8 & 4390.0 \\
\hline $\mathrm{T} \times 0 \%$ & 61.13 & 219.3 & 1937.8 & 2840.6 & 3645.9 \\
\hline $\mathrm{T} \times 5 \%$ & 61.86 & 215.5 & 2013.5 & 2982.5 & 3967.0 \\
\hline $\mathrm{T} \times 10 \%$ & 59.90 & 216.1 & 2025.0 & 3099.0 & 4206.0 \\
\hline$\pm \mathrm{SEM}$ & 0.13 & 0.37 & 5.20 & 39.30 & 40.10 \\
\hline
\end{tabular}

a, $b$ and c: Means in the same column for each factor having different superscripts are significantly different (P $\leq 0.05)$.

\section{Body weight gain:}

Data illustrated in Fig. (1) revealed that body weight gain (BWG) was the highest for chicks sprayed with $10 \% \mathrm{KI}$, moderate for those sprayed with $5 \% \mathrm{KI}$ and the lowest for control chicks without KI treatment at all interval studied and during the whole experimental period.

As affected by spraying time, spraying the chicks once/week had no effect on BWG of chicks at all intervals studied, but the effect of spraying for once/week cleared during the whole experimental period (0-60 d of age), whereas chicks sprayed once/week significantly $(\mathrm{P}<0.05)$ increased $\mathrm{BWG}$ as compared to twice/week (Fig. 2).

The effect of interaction between treatment and spraying time was significant $(\mathrm{P}<0.05)$ during the interval from $0-60 \mathrm{~d}$, reflecting the highest $\mathrm{BWG}$ of chicks sprayed with KI at a level of $10 \%$ for once/week (Fig. 3)

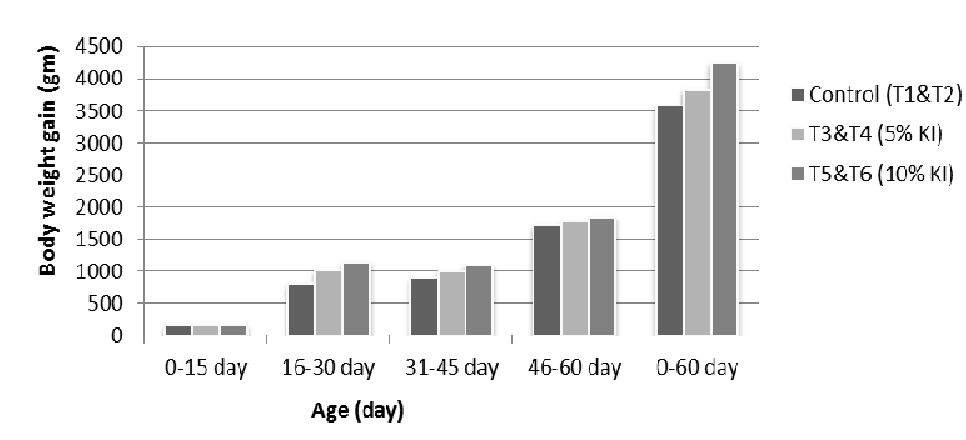

Figure 1: Effect of treatment on body weight gain 

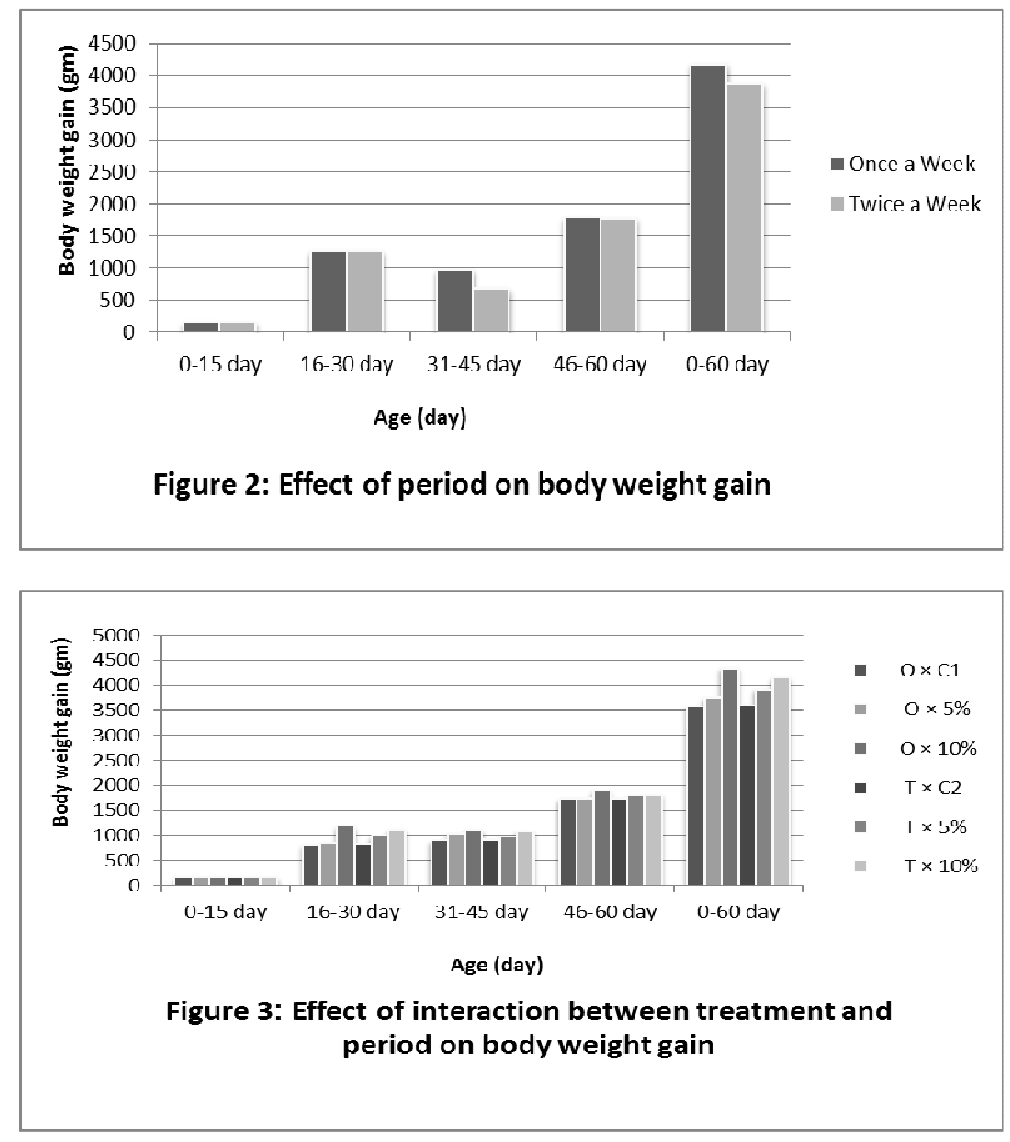

\section{Blood components:}

\section{Hematological parameters:}

Data shown in Table (4) revealed insignificant effect of KI treatment on count of RBCs, but both KI levels significantly $(\mathrm{P}<0.05)$ increased count of WBCs and blood hemoglobin $(\mathrm{Hb})$ concentration as compared to control. Treatment with KI at a level of $10 \%$ showed significantly $(\mathrm{P}<0.05)$ the highest $\mathrm{WBC}$ s count and $\mathrm{Hb}$ concentration.

The effect of spraying time was significant only on WBCs count. Count of WBCs was significantly
$(\mathrm{P}<0.05)$ higher by spraying the chicks twice/week than once/week. However, RBCs count and Hb concentration were nearly similar as affected by spraying time (Table 4).

The effect of interaction between treatment and spraying time was significant $(\mathrm{P}<0.05)$ on $\mathrm{WBC}$ count and $\mathrm{Hb}$ concentration. Therefore, chicks sprayed with $10 \% \mathrm{KI}$ twice/week showed the highest values as compared to other treatments (Table 4).

Table (4): Hematological parameters of turkey chicks as affected by treatment, spraying time and their interaction.

\begin{tabular}{|c|c|c|c|}
\hline Variable & $\operatorname{RBCs}\left(\times 10^{6} / \mathrm{mm}^{3}\right)$ & $\begin{array}{l}\text { Hematological parameter } \\
\text { WBCs }\left(x^{3} / \mathrm{mm}^{3}\right)\end{array}$ & Hemoglobin (g/dl) \\
\hline \multicolumn{4}{|c|}{ Effect of treatment (KI level): } \\
\hline $0 \%$ & 3.49 & $4.99^{\mathrm{c}}$ & $9.74^{\mathrm{b}}$ \\
\hline $5 \%$ & 4.65 & $5.21^{\mathrm{b}}$ & $10.23^{\mathrm{a}}$ \\
\hline $10 \%$ & 4.74 & $7.01^{\mathrm{a}}$ & $10.67^{\mathrm{a}}$ \\
\hline \pm SEM & 0.14 & 0.18 & 0.02 \\
\hline \multicolumn{4}{|c|}{ Effect of spraying time/week: } \\
\hline Once $(\mathrm{O})$ & 4.31 & $5.52^{\mathrm{b}}$ & 10.14 \\
\hline Twice $(\mathrm{T})$ & 4.26 & $5.96^{\mathrm{a}}$ & 10.29 \\
\hline \pm SEM & 0.11 & 0.32 & 0.10 \\
\hline \multicolumn{4}{|c|}{ Interaction between treatment and spraying time: : } \\
\hline $\mathrm{O} \times 0 \%$ & 3.50 & 4.99 & 9.74 \\
\hline $\mathrm{O} \times 5 \%$ & 4.64 & 5.10 & 10.21 \\
\hline $\mathrm{O} \times 10 \%$ & 4.80 & 6.45 & 10.48 \\
\hline $\mathrm{T} \times 0 \%$ & 3.48 & 4.99 & 9.75 \\
\hline $\mathrm{T} \times 5 \%$ & 4.65 & 5.32 & 10.26 \\
\hline $\mathrm{T} \times 10 \%$ & 4.67 & 7.56 & 10.86 \\
\hline \pm SEM & 0.13 & 0.16 & 0.03 \\
\hline
\end{tabular}

a, $b$ and c: Means in the same column for each factor having different superscripts are significantly different $(\mathrm{P} \leq \mathbf{0 . 0 5})$. 


\section{Blood serum biochemicals:}

Data presented in Table (5) showed significant $(\mathrm{P}<0.05)$ increase in serum total protein $(\mathrm{TP})$ concentration only with KI treatment at a level of $10 \%$ as compared to control, but did not differ from that with $5 \%$ KI. The observed significant increase in TP concentration was associated with significant $(\mathrm{P}<0.05)$ increase in globulin (GL) not in albumin (AL) concentration as affected by $10 \% \mathrm{KI}$. However, AL/GL ratio significantly $(\mathrm{P}<0.05)$ increased with $5 \% \mathrm{KI}$ as compared to control, but did not differ from that with $10 \% \mathrm{KI}$.
It is of interest to note that the effect of spraying time was not significant on concentration of TP, AL, $\mathrm{GL}$ and $\mathrm{AL} / \mathrm{GL}$ ratio. The effect of interaction between treatment and spraying time was insignificant on TP, $\mathrm{AL}$ and GL concentrations. This was reflected in similar trend of increase in TP, AL and GL by increasing KI level either by spraying once or twice/week, being the highest for chicks treated with $10 \% \mathrm{KI}$ twice/week. However, the effect of interaction between treatment and spraying time on $\mathrm{AL} / \mathrm{GL}$ ratio was significant $(\mathrm{P}<0.05)$, reflecting the highest $\mathrm{AL} / \mathrm{GL}$ ratio for chicks treated with 5\% KI once/week (Table 5).

Table (5): Biochemical parameters in blood serum of turkey chicks as affected by treatment, spraying time and their interaction.

\begin{tabular}{|c|c|c|c|c|}
\hline \multirow[b]{2}{*}{ Variable } & \multirow[b]{2}{*}{$\begin{array}{l}\text { Total protein } \\
\text { (g/dl) }\end{array}$} & \multicolumn{2}{|c|}{ Blood serum biochemical } & \multirow[b]{2}{*}{$\begin{array}{c}\text { Albumin/globulin } \\
\text { ratio }\end{array}$} \\
\hline & & $\begin{array}{l}\text { Albumin } \\
(\mathrm{g} / \mathrm{dl})\end{array}$ & $\begin{array}{l}\text { Globulin } \\
\text { (g/dl) }\end{array}$ & \\
\hline \multicolumn{5}{|c|}{ Effect of treatment (KI level): } \\
\hline $0 \%$ & $4.11^{\mathrm{b}}$ & 2.44 & $1.67^{\mathrm{b}}$ & $1.46^{\mathrm{b}}$ \\
\hline $5 \%$ & $4.53^{\mathrm{ab}}$ & 2.84 & $1.69^{\mathrm{b}}$ & $1.68^{\mathrm{a}}$ \\
\hline $10 \%$ & $4.78^{\mathrm{a}}$ & 2.92 & $1.86^{\mathrm{a}}$ & $1.57^{\mathrm{ab}}$ \\
\hline \pm SEM & 0.14 & 0.18 & 0.02 & 0.04 \\
\hline \multicolumn{5}{|c|}{ Effect of spraying time/week: } \\
\hline Once $(\mathrm{O})$ & 4.35 & 2.72 & 1.63 & 1.67 \\
\hline Twice $(\mathrm{T})$ & 4.60 & 2.73 & 1.87 & 1.46 \\
\hline \pm SEM & 0.11 & 0.32 & 0.10 & 0.13 \\
\hline \multicolumn{5}{|c|}{ Interaction between treatment and spraying time: : } \\
\hline $\mathrm{O} \times 0 \%$ & 4.12 & 2.42 & 1.70 & 1.42 \\
\hline $\mathrm{O} \times 5 \%$ & 4.32 & 2.85 & 1.47 & 1.94 \\
\hline $\mathrm{O} \times 10 \%$ & 4.60 & 2.87 & 1.73 & 1.66 \\
\hline $\mathrm{T} \times 0 \%$ & 4.10 & 2.47 & 1.63 & 1.51 \\
\hline $\mathrm{T} \times 5 \%$ & 4.74 & 2.83 & 1.91 & 1.48 \\
\hline $\mathrm{T} \times 10 \%$ & 4.96 & 2.89 & 2.07 & 1.40 \\
\hline \pm SEM & 0.13 & 0.16 & 0.03 & 0.02 \\
\hline
\end{tabular}

a, $b$ and c: Means in the same column for each factor having different superscripts are significantly different $(\mathbf{P} \leq 0.05)$.

\section{Enzyme activity and T3 concentration:}

Results presented in Table (6) showed insignificant differences among treatments in AST and ALT activities. However, serum T3 concentration was significantly $(\mathrm{P}<0.05)$ the highest in chicks treated with $10 \% \mathrm{KI}$, followed by those treated with $5 \% \mathrm{KI}$ and the lowest in control, respectively.
The effect of spraying time was also significant $(\mathrm{P}<0.05)$ only on $\mathrm{T} 3$ concentration, being higher by spraying the chicks twice than once/week. As affected by insignificant interaction between treatment and spraying time, chicks treated with $10 \% \mathrm{KI}$ twice/week showed the lowest AST and ALT activities and the highest $\mathrm{T}_{3}$ concentration in blood serum (Table 6).

Table (6): Activity of transaminases (AST and ALT) and T3 concentration in blood serum of turkey chicks as affected by treatment, spraying time and their interaction.

\begin{tabular}{|c|c|c|c|}
\hline Variable & $\operatorname{AST}(\mathrm{U} / \mathrm{L})$ & ALT (U/L) & $T_{3}(\mathrm{ng} / \mathrm{dl})$ \\
\hline \multicolumn{4}{|c|}{ Effect of treatment (KI level): } \\
\hline $0 \%$ & 11.96 & 2.57 & $72.05^{\mathrm{c}}$ \\
\hline $5 \%$ & 11.84 & 2.28 & $73.83^{\mathrm{b}}$ \\
\hline $10 \%$ & 11.16 & 2.01 & $82.30^{\mathrm{a}}$ \\
\hline \pm SEM & 0.14 & 0.18 & 0.12 \\
\hline \multicolumn{4}{|c|}{ Effect of spraying time/week: } \\
\hline Once $(\mathrm{O})$ & 11.76 & 2.44 & $74.21^{\mathrm{b}}$ \\
\hline Twice (T) & 11.56 & 2.14 & $77.91^{\mathrm{a}}$ \\
\hline \pm SEM & 0.17 & 0.15 & 0.10 \\
\hline \multicolumn{4}{|c|}{ Interaction between treatment and spraying time: : } \\
\hline $\mathrm{O} \times 0 \%$ & 11.98 & 2.57 & 72.13 \\
\hline $\mathrm{O} \times 5 \%$ & 11.86 & 2.45 & 74.31 \\
\hline $\mathrm{O} \times 10 \%$ & 11.44 & 2.29 & 76.19 \\
\hline $\mathrm{T} \times 0 \%$ & 11.95 & 2.55 & 71.98 \\
\hline $\mathrm{T} \times 5 \%$ & 11.82 & 2.11 & 73.35 \\
\hline $\mathrm{T} \times 10 \%$ & 10.88 & 1.74 & 88.42 \\
\hline \pm SEM & 0.13 & 0.16 & 0.03 \\
\hline
\end{tabular}

a, $b$ and c: Means in the same column for each factor having different superscripts are significantly different $(\mathrm{P} \leq 0.05)$ 
Immune response:

Results shown in Table (7) revealed that chicks treated with $10 \%$ KI showed significantly $(\mathrm{P}<0.05)$ the highest antibody titer $\left(\log _{2}\right)$ against sheep red blood cells (SRBC's) and the lowest lysozyme concentration, followed by those treated with $5 \% \mathrm{KI}$, while the control chicks showed significantly $(\mathrm{P}<0.05)$ the lowest antibody titer and the highest lysozyme concentration.
Spraying chicks twice/week significantly $(\mathrm{P}<0.05)$ increased antibody titer and decreased lysozyme concentration. Accordingly, the insignificant interaction between treatment and spraying time on both parameters reflected the highest immune response for chicks treated with $10 \% \mathrm{KI}$ twice/week (Table 7).

Table (7): Immune response of turkey chicks as affected by treatment, spraying time and their interaction at different ages.

\begin{tabular}{|c|c|c|}
\hline Variable & Antibody titer & Lysozyme ( $\mu \mathrm{mol} / \mathrm{ml})$ \\
\hline \multicolumn{3}{|c|}{ Effect of treatment (KI level): } \\
\hline $0 \%$ & $3.73^{\mathrm{c}}$ & $85.26^{\mathrm{a}}$ \\
\hline $5 \%$ & $4.95^{\mathrm{b}}$ & $82.90^{\mathrm{b}}$ \\
\hline $10 \%$ & $5.30^{\mathrm{a}}$ & $80.21^{\mathrm{c}}$ \\
\hline \pm SEM & 0.04 & 0.22 \\
\hline \multicolumn{3}{|c|}{ Effect of spraying time/week: } \\
\hline Once $(\mathrm{O})$ & $4.33^{b}$ & $85.12^{\mathrm{a}}$ \\
\hline Twice $(\mathrm{T})$ & $4.97^{\mathrm{a}}$ & $80.46^{\mathrm{b}}$ \\
\hline \pm SEM & 0.03 & 0.10 \\
\hline \multicolumn{3}{|c|}{ Interaction between treatment and spraying time: : } \\
\hline $\mathrm{O} \times 0 \%$ & 3.70 & 88.76 \\
\hline $\mathrm{O} \times 5 \%$ & 4.50 & 84.60 \\
\hline $\mathrm{O} \times 10 \%$ & 4.80 & 82.00 \\
\hline $\mathrm{T} \times 0 \%$ & 3.75 & 81.76 \\
\hline $\mathrm{T} \times 5 \%$ & 5.40 & 81.20 \\
\hline $\mathrm{T} \times 10 \%$ & 5.80 & 78.42 \\
\hline \pm SEM & 0.02 & 0.43 \\
\hline
\end{tabular}

a, b and c: Means in the same column for each factor having different superscripts are significantly different (P $\leq 0.05)$.

\section{DISCUSSION}

The current study aimed to evaluate the effect of spraying potassium iodide (KI) on productive performance, blood parameters and immune response of growing turkey chicks during the first 60 days of age. The obtained results indicated heaviest LBW and gain of chicks treated with KI at both levels, being significantly $(\mathrm{P}<0.05)$ higher with $\mathrm{KI}$ at a level of $10 \%$ than $5 \%$. Such results may be due to the important role of iodine in the metabolism and growth, since it has a direct effect on regulation of some metabolic hormones such as thyroid hormones (Magilvery, 1979; El-kaiaty et al., 2004). It is well known that the iodine deficiency causes a low level of $\mathrm{T}_{4}$ and $\mathrm{T}_{3}$ in poultry (Guo, 1999), pigs (Schone et al., 1988), rats (Fang, 2000) and humans (Orville et al., 2000). Thyroid hormones are synergistic to growth hormone and there are many actions of thyroid hormones mediated to stimulation of cellular protein synthesis (Hinkle and Kinsella, 1986; Abd El-Latif et al., 2001). In this respect, Fabris (1973) observed that iodine deficiency had a reverse effect on the rat's lymphocytes function. Also, Bagchi et al. (1985) explained that excessive consumption of iodine may be responsible for the increased incidence of autoimmune thyroiditis in chickens. They found that administration of iodine during the first 10 weeks of life increased the incidence of auto antibodies to triiodothyronine, thyroxine and thyroglobulin, therefore improve growth rate. Moreover, Vorotnitskaya et al. (1989) reported that all trace elements mixture affecting live weight gain, feed utilization. Other investigators found that $\mathrm{KI}$ had antimicrobial effects against wide range of microbes, gram negative-positive bacteria species, due to developing of general healthy condition that led to enhance growth performance (Cooper, 2007).

It is worthy noting that the observed improvement in LBW and gain of chicks treated with $10 \% \mathrm{KI}$ was associated with insignificant increase in RBCs count and significant $(\mathrm{P}<0.05)$ increase in WBCs count and $\mathrm{Hb}$ concentration. Also, this was attributed to significant $(\mathrm{P}<0.05)$ increase in total protein and globulin in blood serum. Although, El-Kaiaty et al. (2004) found that AST and ALT significantly decreased by iodine treatment in ducks, the present results indicated insignificant reduction in AST and ALT activities by KI treatment at both levels. These finding may indicate normal liver function of chicks treated with $\mathrm{KI}$.

Lysozymes are proteins of low molecular weight found in polymorphnuclear leukocytes and mononuclear cells. They are present in all tissue fluids except cerebro spinal fluid, sweat and urine. Lysozymes are considered as a member of the innate humoral factors that elaborated from the body and showed a dramatic increase in concentration in response to infection or tissue injury (Weir, 1983). The effect of iodine on increasing the antibody titer and decreasing lysozyme concentration may be attributed to an indirect effect on the immune system, whereas chicks treated with KI were highly producer of antibody to SRBC's and reduced lysozyme concentration. Accordingly these birds had better immunological responsiveness than control birds. KI may preferentially affect cell-mediated 
immune response relative to development of lymphoid organs and antibody production, because iodine may act by altering antigen presentation by the thyroid epithelial cells modifying the function of thyroid targeted immune cells or by other mechanisms (Bagchi et al., 1985; Sonsovskaya, 1999). Also, thyroid hormones are known to influence the function and development of lymphoid organs (Paavonen, 1982).

It could be concluded that potassium iodide had positive effect on turkey chicks when used as spraying over heads of growing chicks with $10 \%$ twice a week.

\section{REFERENCES}

Abd El-Latif, S.A.; Faten, A. Ibrahim, EL-Kaiaty, A.M.; and Abd El-Moty, A.K.I (2001). Effect of iodine on some productive and metabolic functions of growing Muscovy Ducklings. Egypt. J. of Nutrition and feed, Vol. 4 (special Issue): 1015 1023.

Bagchi, N.; Brown, T.R.; and Urdanivia, E. (1985). Induction of Autoimmune Thyroiditis in chickens by dietary Iodine. Science, Vol 230: 325-327.

Chen, Y. (1980). Effect of thyroxine on the immune response of mice in vivo and in vitro. Immunol. Comm. 9(3):269.

Cooper, R.A. (2007). Iodine revisited. International Wound Journal, 00:1-4.

Darras, V.M.; Visser, T.J.; Berghman, L.R.; and Kuhn, E.R. (1992). Ontogeny of type I and III deiodinase activities in embryonic and posthach chick: relationship with changes in plasma triiodothyronine and growth hormone level. Comparative Biochemistry and Physiology, 103 A: 131-136.

Drew, P.R.; Charles, J.S.; Trevor, B.; and John, L. (2004). Oxford Handbook of Clinical Haematology. 2th Edition, Oxford University Press, USA.

Duncan, D.B. (1955). Multiple range and multiple F test. Biometries 11:1-42.

El-Kaiaty, A.M. , Faten, A. A. Ibrahim and Nematallah G. M. Ali. (2004). Responses in growth, blood constituents, physiological functions and immune responses due to iodede injection of growing Miscovy ducklings. Egypt. Puolt. Sci., Vol., 24 (IV) : (787-805).

Fabris, N. (1973). Immunodepression in thyroid-deprived animals. Clin. Exper. Immunol. 15:601-611.

Fang, H. (2000). The study on the effects of iodine deficiency and iodine excess on the expression on thyroid TG and TPO mRNA in rats. Ph.D. Thesis, Tianjin Medical University, China.

Gado, M.S., (1996). Endocrine Physiology: $2^{\text {th }}$ Edition. 159-165, Cairo, Egypt.

Ganong, W. F. (2001). Review of Medical Physiology, Twentieth Edition. New York: McGraw-Hill, Inc., pp. 307-321.
Guo, Y. M. (1999). The necessity of selenium to normal thyroid hormone metabolism and the influence of selenium deficiency on the metabolism of sulphur-containing compounds. Ph.D. Thesis, China Agricultural University.

Hadlly, M.C. (1992). Endocrinology $3^{\text {rd }}$ ed Prentic-Hall Iternational. Inc.

Hamdy, A.M.M., and S.A. Abdel- Latif, (1999). Effect of iodinated water on some productive and metabolic parameters of japanese quail hens. Egyptian J. Nutrition and Feeds (1999) 2 (Special Issue): 703-709.

Hawkey, C.M. and Dennett, T.B. (1989). A Color Atlas of Comparative Veterinary Hematology. Wolf Publishing Limited, London, England.

Hetzel, B.S. and M.C. Welby. (1997). Iodine. In: O'Dell, B.L. and Sunde, R.A. (eds.) Handbook of Nutritionally Essential Mineral Elements. Marcel Dekker, New York, p 557.

Hinkle, P.M.; and Kinsella, P.A. (1986). Thyroid hormone activity iodination of an autocrine growth factor by pituitary tumor cell. Science, 234: 154 .

Magilvery, R.W. (1979). Biochemistry A. Functional. Approach. PP. 711, W.B. Saunder Company, Philadelphia, London, Toronto.

McDowell, L.R. (2003). Minerals in animal and human nutrition, $2^{\text {nd }}$ edn. Elsevier, Amsterdam, pp. 305334.

McNabb, F.M.A.; and King, D.B. (1993). Thyroid hormones in growth, metabolism and development. Pp.393-417 in the Endocrinology of growth, development and metabolism in vertebrate P.K.T. Pang and M. T. Schreibman, ed. Academic Press, New York, NY, USA.

National Research Council (1994). Nutrient Requirements of Poultry [M], Ninth Revised Edition. National Academy Press, 1994, Washington, DC.

Orville, A. Levander and Philip, D. Whanger. (2000). Deliberations and evaluations of the approaches, endpoints and paradigms for selenium and iodine dietary recommendations. J. Nutr. 126:2427s-2434s.

Paavonen, T. (1982). Enhancement of human B lymphocyte differentiation in vitro by thyroid hormone. Scand. J. Immunol. 15:211-215.

Prescott, C.A., B.N. Wilkie, B. Hunter and R.J. Julian (1982). Influence of purified grade pentachlorphenol on the immune response of chickens. American Journal of Vetrinary Reseach, 43:481-487.

SAS (1995). Statistical Analysis System, User's Guide Version 5, Cary NC, USA.

Schltz, L.A., (1987). Methods in Clinical Chemistry. The C.V. Mosby Cost Louis, 742-746.

Schone, F., H. Ludke, A. Hennig and G. Jahreis (1988). Copper and iodine in pig diets with high glucosinolate rapseed meal: II. Influence of iodine in pig diets with rapseed meal untreated or treated with copper ions on performance and thyroid hormone status of growing pigs. Anim. Feed Sci. Technol. 22:45-59. 


\section{El-Sawy, M.A. and Samya E. Ibraheim}

Sosnovskaya, T. (1999). Efficacy of Izamben in poultry. Vestsi- Akademii-Agrarnykh -Navuk Respubliki Belarus, 1999 No 2: 82-85 (Abstract).

Sturkie, P.D. (1986). Avian Physiology, $4^{\text {th }}$ ed. Comstock Associate, UY, USA.

Turner, C.D.; and Bagna, J.T. (1971). General Endocrinology 5th ed. W.B. Saunders Company Philadelphia, London, Toronto.
Vorotnitskaya, I.E.; Solov, V.A.; Yagodin, B.A.; and Gubar, G.D. (1989). A short review of the results of studies on problems of trace elements in biology in 1987. Mikroelementary-V-SSSR 30:37-50.

Weir, D.M., (1983). Immunology: An out line for students of medicine and biology. $5^{\text {th }}$ Ed. 15-16, Churchill Livingstone Edinburgh, London Melbourne, New York.

Zhigang Song, Yuming Guo* and Jianmin Yuan, (2006). Effects of Dietary Iodine and Selenium on the Activities of Blood Lymphocytes in Laying Hens, Asian-Aust. J. Anim. Sci. Vol 19, No. $5: 713-719$.

\section{تأثير الرش بيوديد البوتاسيوم على الأداء الإنتاجى وقياسات الدم والاستجابة المناعية لكتاكيت الرومى إئم

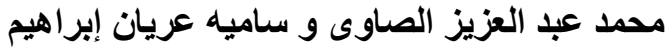

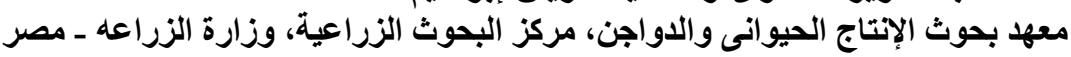

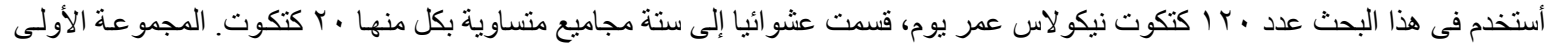



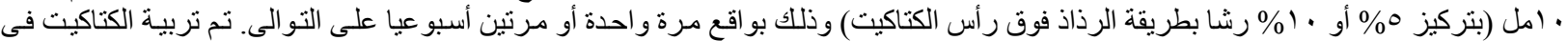



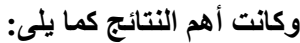

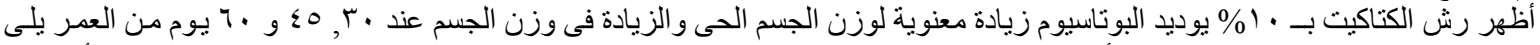



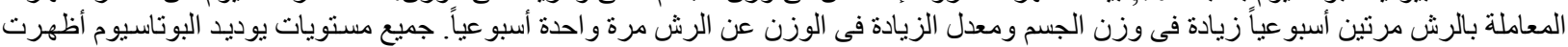

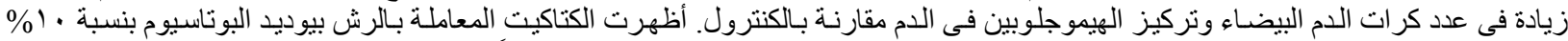

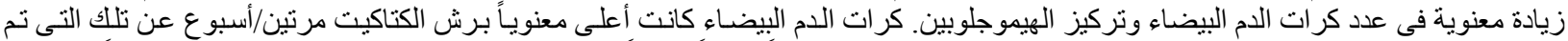

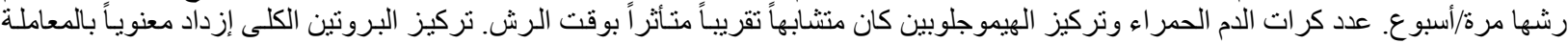

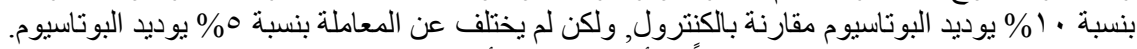

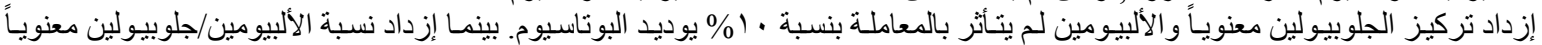



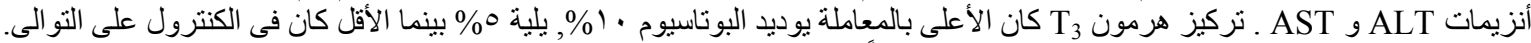
تركيز هرومن

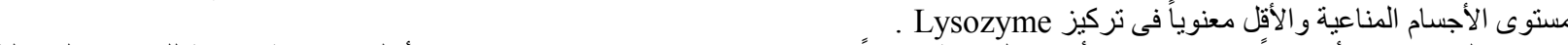

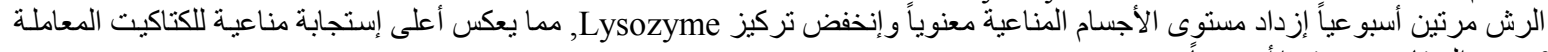

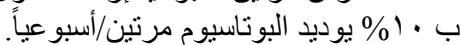



